A N N A L E S

UNIVERSITATIS MARIAE CURIE-SKŁODOWSKA LUBLIN - POLONIA

VOL. LXX, z. 2

SECTIO B

2015

Katedra Geotechniki

Zachodniopomorski Uniwersytet Technologiczny w Szczecinie

cyprian@zut.edu.pl, seulcyprian@wp.pl

\title{
CYPRIAN SEUL
}

\section{Warunki geologiczno-inżynierskie na obszarze strefy krawędziowej Wzgórz Warszewskich}

Engineering-geological conditions in the edge zone of the Warszewo Hills

Słowa kluczowe: Wzniesienia Szczecińskie, strefa krawędziowa, procesy geodynamiczne, iły septariowe, parametry geotechniczne, awarie budowlane

Key words: Szczecińskie Hills, edge zone, morainic plateau, geodynamic process, septaria clay, geotechnical parameters, building failures

\section{ZARYS TREŚCI}

Rozwój budownictwa na przełomie XX i XXI w. przyczynił się do przeznaczania terenów wokół miast dla celów budowlanych, zarówno mieszkaniowych i usługowych, jak i przemysłowych. Jednym z takich obszarów są północne dzielnice Szczecina. Strefa krawędziowa wysoczyzny morenowej charakteryzuje się znacznymi deniwelacjami, a co się z tym wiąże, wzmożonymi procesami geodynamicznymi. W pracy przedstawiono charakterystykę morfologiczną form terenu występujących w szeroko pojętej strefie krawędziowej. Wydzielono trzy podstawowe obszary (część wysoczyznowa, stok, zbocze), oraz podnóże stoku, dla których przedstawiono podstawowe cechy geologiczno-inżynierskie oraz problemy, jakie się pojawiają podczas posadowienia oraz w czasie eksploatacji obiektów inżynierskich, a także skutki nieprzemyślanej ingerencji w środowisko przyrodnicze i konsekwencje wynikające $\mathrm{z}$ rozpoznania błędnie lokalnie podłoża gruntowego.

\section{WSTĘP}

Tendencje rozwojowe współczesnego miasta zakładają zmniejszenie liczby mieszkańców w jego centrum, a tym samym budowę na obrzeżach miasta osiedli 
mieszkaniowych (sypialnie). Jednym z potencjalnych miejsc rozwoju Szczecina jest obszar tak zwanych Wzgórz Warszewskich. W ciągu ostatnich 20 lat obszar wykorzystywany rolniczo lub rekreacyjnie (ogródki działkowe) został przeznaczony pod zabudowę rozproszoną (małe osiedla domków jednorodzinnych oraz wielorodzinne osiedla o niskiej zabudowie). Rozbudowywano również sieć dróg osiedlowych oraz głównych ciągów komunikacyjnych między Szczecinem a Policami. Podczas prac ziemnych stare systemy melioracyjne zostały zniszczone. Powodowało to zmiany stosunków wilgotnościowych w podłożu gruntowym, które wpływają na niektóre procesy geodynamiczne (np. pęcznienie, procesy osuwiskowe, spełzywanie). Zmniejszenie powierzchni infiltracyjnej dla wód opadowych na skutek budowy dróg chodników itp. powoduje zwiększenie spływu powierzchniowego wód opadowych, a przez to wzmożenie procesów niszczących (między innymi erozji podłoża czy też lokalnie sufozji). W niniejszej pracy przedstawiono ogólnie budowę geologiczną, charakterystykę morfologiczną oraz warunki wodne Wzgórz Warszewskich pod kątem oceny podłoża budowlanego oraz jego wpływu na posadowienie i eksploatację obiektów budowlanych na omawianym obszarze. Północny rejon Szczecina charakteryzuje się trudnymi warunkami geologicznoinżynierskimi. W dalszej części pracy podano przykłady posadowienia obiektów w strefie krawędziowej wysoczyzny, problemy, z jakimi spotykają się projektanci, a także skutki wynikające ze zmian parametrów wytrzymałościowych w gruncie, między innymi w wyniku ingerencji człowieka.

\section{POŁOŻENIE WZGÓRZ WARSZEWSKICH}

W północno-zachodniej Polsce między Szczecinem a Policami na lewym brzegu Odry naprzeciw jeziora Dąbie znajdują się Wzgórza Warszewskie. Administracyjnie obszar należy do powiatu szczecińskiego i polickiego. Według podziału Kondrackiego (2000), obszar Wzgórz Warszewskich należy do Wzniesień Szczecińskich (313.26), które wchodzą w skład Pobrzeża Szczecińskiego będącego częścią Pobrzeża Południowobałtyckiego (Ryc. 1).

Od wschodu obszar ogranicza dolina Dolnej Odry, od południa i południowego zachodu obniżenie niecki Niebuszewa, a od zachodu i północy obniżenie doliny równiny Wkrzańskiej (Borówka 2002).

Najwyższy punkt znajduje się w północnej części Szczecina w dzielnicy Warszewo i wynosi 130,9 m n.p.m. (Wielecka Góra). Najniższy, to poziom Odry (ok. 0,0 m n.p.m.). Rozciągłość równoleżnikowa i południkowa wynosi około $8 \mathrm{~km}$.

W krajobrazie wysoczyzny wyróżnia się wzniesienie na obrzeżach, poprzecinane głęboko wciętymi dolinkami, co nadaje „górzysty charakter” omawianemu obszarowi (Ryc. 2). 


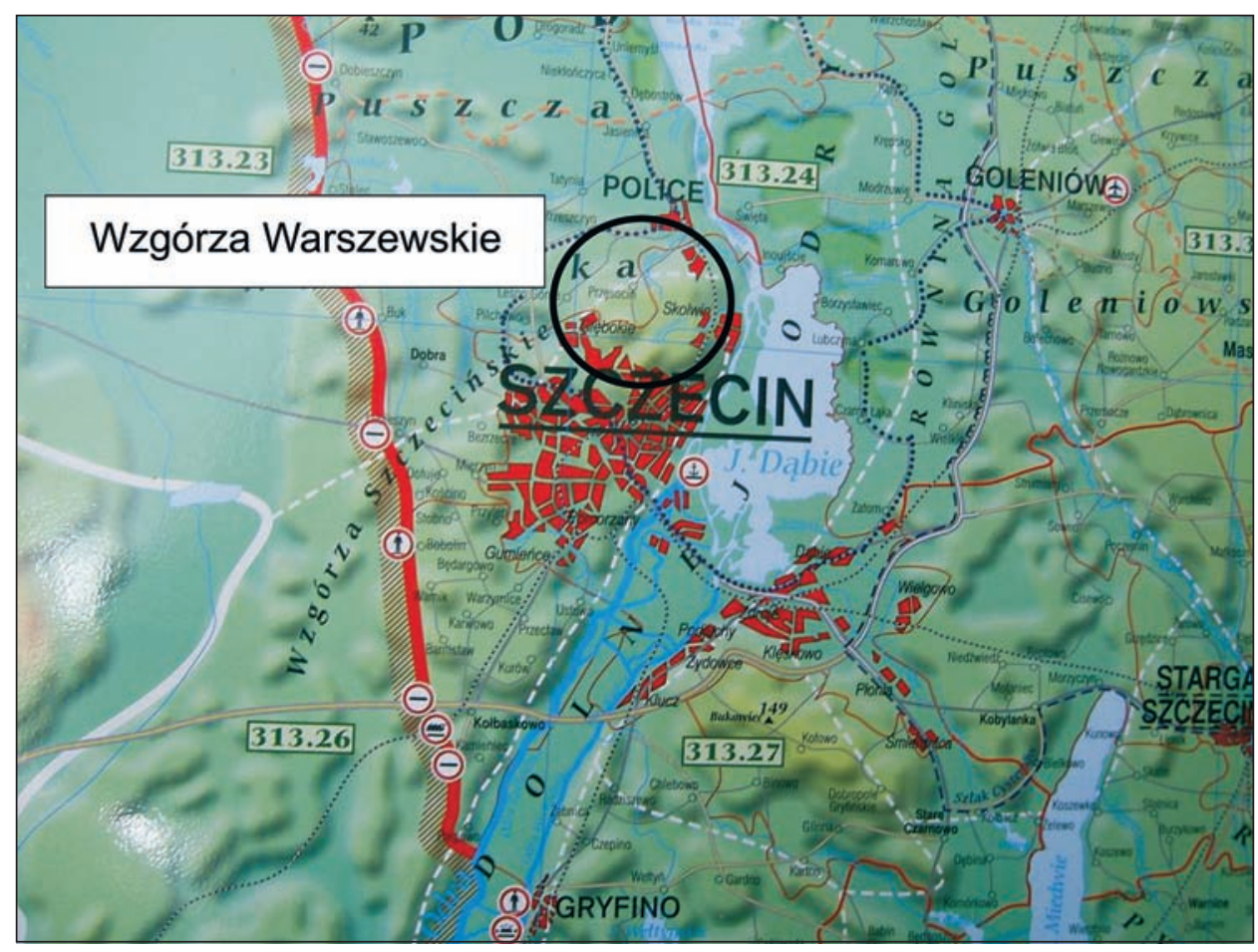

Ryc. 1. Położenie Wzgórz Warszewskich

Fig. 1. Location of Warszewo Hills

\section{OGÓLNA CHARAKTERYSTYKA MORFOLOGICZNA}

Pod względem morfologicznym Wzgórza Warszewskie są znacznie urozmaicone. Występują tu formy pochodzenia lodowcowego, wodnolodowcowego, rzecznego, eolicznego, denudacyjnego oraz antropogenicznego.

Formy pochodzenia lodowcowego obejmują wyższe partie Wysoczyzny Warszewskiej i reprezentowane są przez wzgórza morenowe o wysokościach względnych dochodzących do $10 \mathrm{~m}$. Jedynie w północnej części omawianego obszaru występuje niewielki fragment wysoczyzny morenowej płaskiej o deniwelacjach mniejszych niż $2 \mathrm{~m}$. Warto zaznaczyć, że cała wysoczyzna Wzniesień Szczecińskich powstała w czasie wcześniejszych zlodowaceń, a ostatnie nasunięcie tylko przemodelowało starsze formy przykrywające je cienką warstwą osadów ostatniego zlodowacenia. Wysoczyzna morenowa zbudowana jest z zaburzonych osadów glacjalnych przemieszanych z oligoceńskimi piaskami i iłami septariowymi z piaskami i glinami (Berendt 1921). Obszar wysoczyznowy charakteryzuje się znaczną zmiennością warstw. Występują liczne deformacje glacitektoniczne 


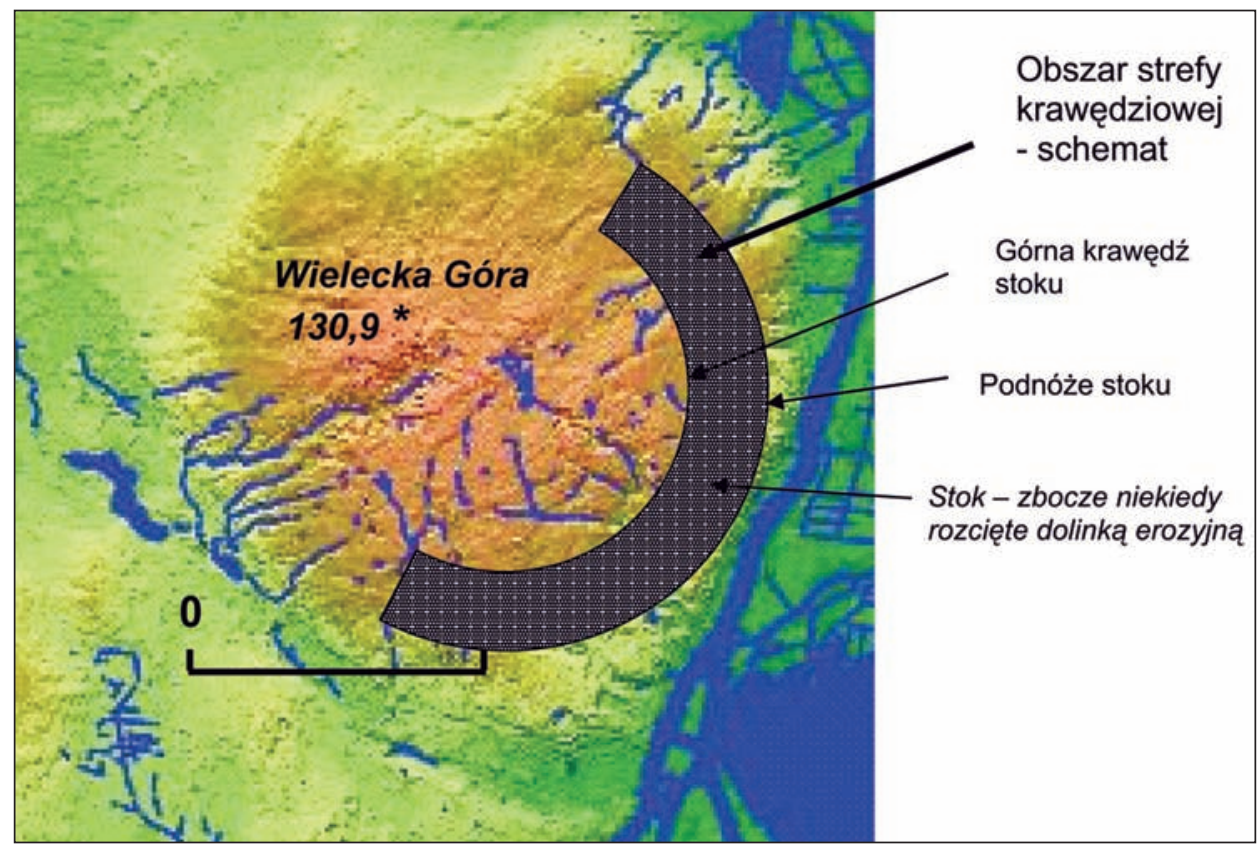

Ryc. 2. Szkic hipsometryczny (http://gis.um.szczecin.pl) - położenie strefy krawędziowej

Fig. 2. Hypsometric sketch (http://gis.um.szczecin.pl) - the location of the edge zone

z wyciśniętymi łuskami iłów oligoceńskich, a nawet fragmentów węgli brunatnych (lignitu). Współczynniki zmienności poziomej [Wzp] Kowalskiego (1988) wynoszą niekiedy powyżej 30. Spadki terenu w strefie krawędziowej wysoczyzny są znaczne i często przekraczają 15\%. Na obszarach wierzchowinowych występują często bezodpływowe obniżenia (okresowo lub stale wypełnione wodą) oraz dolinki (tylko niektóre z nich wykorzystywane są przez cieki).

Formy pochodzenia wodnolodowcowego występują przeważnie na obrzeżach Wysoczyzny z wyjątkiem obniżenia doliny Odry w postaci nieciągłych płatów. W południowej części przyklejone do wysoczyzny morenowej są terasy kemowe powstałe w końcowej fazie arealnego zaniku pokrywy lodowej podczas tworzenia się obniżenia Niecki Niebuszewa. Od strony zachodniej i północnej terasy kemowe przechodzą w równinę. Na obszarze Wzgórz Warszewskich występują też pojedyncze niewielkie pagórki kemowe. Wody lodowcowe z okresu wytapiania wytworzyły liczne dolinki oraz niewielkie zagłębienia po martwym lodzie. Utwory kemowe zbudowane są z piasków pylastych, drobnych i średnich, często przewarstwionych piaszczystymi pyłami, a nawet glinami pylastymi. Maskują one urozmaiconą rzeźbę lodowcową. Układ warstw utworów kemowych jest przeważnie prosty lub złożony. Współczynniki zmienności [Wzp] nie przekraczają 10. Powstałe dolinki erozyjne wycięte są przeważnie w osadach 
lodowcowych, a na obrzeżach wysoczyzny w osadach wodnolodowcowych. Dna dolinek wypełnione są osadami piaszczystymi, a nawet organicznymi, często przykrytymi piaskami i glinami deluwialnymi. Jedną z bardziej charakterystycznych rynien glacjalnych rozcinaną i nadbudowywaną w okresach późniejszych jest dolina Żółwinki. Znajduje się ona w północnej części Wzgórz Warszewskich w dzielnicy Szczecina - Skolwin. Odprowadza ona wody w kierunku doliny Odry. W jej dolinie i na obrzeżach obok glin morenowych występują zaburzone glacitektoniczne septariowe iły oligoceńskie oraz piaski i żwiry wodnolodowcowe, a części końcowej znajdują się piaszczyste stożki napływowe. Na stokach doliny Żółwinki występują intensywne procesy osuwiskowe, które przyczyniły się nawet do zmiany lokalizacji projektowanego w latach siedemdziesiątych ubiegłego wieku osiedla mieszkaniowego.

Formy pochodzenia rzecznego są to przeważnie dna dolinek rzecznych, które powstawały pod koniec plejstocenu i w holocenie. Wody opadowe wykorzystywały rynny i doliny fluwioglacjalne, rozcinając i nadbudowując je materiałem piaszczystym i organicznym. Występują one na obszarze zarówno wysoczyznowym, jak i na stokach, rozcinając je oraz u podstawy lokalnej bazy erozyjnej, gdzie miąższość osadów rzecznych jest największa. Od strony wschodniej znajduje się dolina Dolnej Odry nadbudowana kilkoma terasami pochodzenia rzeczno-rozlewiskowego (Karczewski 1968). Od strony południowej u podnóża wysoczyzny w korycie powstała dolina rzeczna, wykorzystując dolinę wód roztopowych powstałą prawdopodobnie jeszcze przed nasunięciem ostatniego lądolodu.

Formy pochodzenia eolicznego występują w postaci niewielkich form wydmowych na zachodnich obrzeżach wysoczyzny, której podłożem są terasy kemowe oraz w północnej części omawianego terenu na terasie kemowej oraz najwyższej terasie rzecznorozlewiskowej. Są to niewielkie wydmy o wysokościach względnych do $2 \mathrm{~m}$, zbudowane z piasków drobnych.

Niekiedy zalegają na wierzchowinach, tworząc niewielkie pokrywy piaszczyste lub na zawietrznych stokach dolinek erozyjnych.

Formy pochodzenia denudacyjnego występują na obszarze Wzgórz Warszewskich przeważnie na obszarach o dużych spadkach terenu. Do najważniejszych można zaliczyć stoki wysoczyzny, na których występują suche dolinki, a u podnóża często stożki napływowe. Podstawowym procesem na stokach są ruchy masowe. Na obszarze strefy krawędziowej zaznaczają się osuwiska. Widoczne są też obszary, na których zachodzi spełzywanie. Zjawiska te występują szczególnie tam, gdzie w podłożu znajdują się zaburzone glacitektoniczne septariowe iły oligoceńskie.

Formy powstałe w wyniku depozycji osadów organicznych. W południowej części u podnóża wysoczyzny Wzgórz Warszewskich w obniżeniu doliny łączącej jezioro Głębokie z doliną Odry znajduje się równina torfowa wypełniająca obniżenia. Na wierzchowinach Wysoczyzny występują niewielkie równiny torfo- 
we wypełniające oczka powstałe po wytopieniu brył martwego lodu. Miąższość utworów organicznych (torfy, namuły a niekiedy gytie) sięga nawet kilku metrów.

Formy pochodzenia antropogenicznego powstały w wyniku działalności człowieka. Do głównych form zaliczyć można wały przeciwpowodziowe i groble w dolinie Odry, różne obiekty liniowe (wykopy i nasypy drogowe przecinające Wysoczyznę oraz nasyp kolejowy ciągnący się w południowej i wschodniej części Wzgórz Warszewskich), pozostałości po kopalniach surowców ceramicznych oraz żwirowniach - wyrobiska i glinianki niekiedy wypełnione wodami opadowymi i infiltracyjnymi. W jednym z wyrobisk po eksploatacji iłów oligoceńskich w ostatnich latach wybudowano osiedle czterokondygnacyjnych budynków mieszkalnych, w których po kilku latach eksploatacji zanotowano pęknięcia i zarysowania. Istniejące wyrobiska w strefie krawędziowej wysoczyzny w niektórych miejscach przyczyniają się do rozwoju osuwisk oraz uruchomienia procesów pełzania, których wcześniej nie notowano.

\section{BUDOWA GEOLOGICZNA}

Obszar Niziny Szczecińskiej leży o obrębie większej jednostki mezozoicznej nazywanej Niecką Szczecińską (Marek 1997; Stupnicka 1989) wchodzącą w skład paleozoicznych waryscyjskich struktur orogenicznych należących do paleozoicznej platformy europejskiej (Dadlez 1983).

Z okresu paleozoiku pozostały skały wulkaniczne, a pod koniec paleozoiku powstawały anhydryty i sole w cyklach solnych (Werra, Stassfurt, Leine, Aller) podścielane wapieniami i dolomitami. Spąg osadów cechsztyńskich zalega poniżej 4 km (Marek 1997). Na skutek halokinezy osady te często przebijają młodsze warstwy w postaci diapirów i poduszek solnych. W omawianym rejonie nie przebijają utworów mezozoicznych.

W triasie deponowane były serie osadowe litofacji wapienno-dolomitycznej (Marek 1997). Prawdopodobnie już wówczas obszar ten połączony był z Morzem Tetydy. Okres jurajski pozostawił miąższe osady wapienne, dolomitowe, wapienno-margliste i margle, na których znajdują się serie ilasto-mułowcowe z syderytami i wapienno-margliste. W okresie kredowym deponowane były osady ilasto-muliste z wkładkami marglistymi lub pirytami czy też fosforytami. Pod koniec kredy (mastrycht) podczas ruchów laramijskich, w czasie regresji morskiej osadzała się kreda pisząca i wapienie margliste, na których nieciągle zalegają krzemionkowo-wapienne opoki. Miąższość osadów mezozoicznych jest znaczna i sięga $3 \mathrm{~km}$.

We wczesnym okresie paleogeńskim obszar Niecki Szczecińskiej był płytkim zbiornikiem wodnym z licznymi wyspami. W głębszych strefach deponowane były osady mułkowo-ilaste, w strefie płytkiej piaski kwarcowe, a po wkroczeniu morza eoceńskiego rozpoczęła się również sedymentacja osadów 
mułkowo-ilastych. W czasie oligocenu deponowane były osady ilaste, w których wytworzyły się konkrecje margliste, ilasto-żelaziste i ilasto-margliste, nazywane septariami. Pod koniec oligocenu w fazie regresji morskiej w płytkich zatokach powstawały serie piasków kwarcowych ze znaczną domieszką konkrecji żelazistych „kule szczecińskie” oraz ilaste piaski łyszczykowe (Piotrowski 1982, 1983). $\mathrm{Na}$ omawianym obszarze we wczesnym miocenie rozwinięta była sieć rzeczna z kierunkiem odpływu ze Skandynawii ku Wielkopolsce. Przeważa akumulacja limniczna. W obniżeniach dolinnych osadzały się piaski i mułki z wkładkami organicznymi. W górnym miocenie i w pliocenie, między innymi na skutek ruchów tektonicznych, rozwinęła się znacznie sieć rzeczna. Powstały głębokie rozcięcia erozyjne niekiedy do utworów eoceńskich, a nawet kredowych. W obniżeniach deponowane były piaski drobne i mułkowe z seriami organicznymi, z których wytworzyły się cienkie pokłady węgli brunatnych.

$\mathrm{Na}$ tak urozmaiconą powierzchnię porozcinaną dolinami erozyjnymi i wypełnioną piaskami, mułkami i iłami w okresie plejstoceńskim nasuwały się kilkakrotnie lądolody skandynawskie. Obecnie podłoże przedczwartorzędowe w rejonie Wzgórz Warszewskich znajduje się na rzędnej od około -30 m n.p.m. do -80 m n.p.m.

Podczas zlodowaceń południowopolskich na obszarze Pomorza Zachodniego nastąpiło najstarsze nasunięcie lądolodu (Dobracki 1982; Piotrowski 1982). Wkraczający lądolód erodował i zaburzał podłoże trzeciorzędowe, poszerzając i pogłębiając obniżenia dolinne Podczas transgresji lądolodu, oprócz egzaracji, podłoże zostało wypełnione piaskami, glinami morenowymi oraz materiałem piaszczystożwirowym. Na obszarze Wzgórz Warszewskich występują dwa poziomy glin morenowych (Dobracki 1982; Piotrowski 1982), rozdzielone lokalnie osadami piaszczystymi. W okresie interglacjału mazowieckiego następowało odtworzenie sieci dolinnej oraz erozja osadów glacjalnych. Na ten okres szacuje się pionowe ruchy neotektoniczne, które znacznie przyczyniały się do erozji. Na taką przeobrażoną powierzchnię wkraczały lądolody zlodowaceń środkowopolskich. Wyróżnia się przynajmniej dwa nasunięcia związane ze zlodowaceniem Odry (Mojski 1995), nazywanym również zlodowaceniem Odry i Warty (Lindner i in. 1995). Nasuniecie lądolodu częściowo zniszczyło i zaburzyło swoje podłoże, tworząc rozległe o miąższe struktury glacitektoniczne (Dobracki 1982). Zostały osadzone wówczas porwaki neogeńskich „piasków szczecińskich” i oligoceńskich iłów septariowych. W przekroju geologicznym Szczegółowej Mapy Geologicznej (ark. Szczecin) widoczne są porwaki utworów przedczwartorzędowych wśród osadów glacjalnych zlodowaceń środkowopolskich (Dobracki 1982) oraz bruki rezydulane na glinach morenowych z okresów interstadialnych. Porwaki glin morenowych i piasków wodnolodowcowych zlodowaceń południowopolskich zmieszanych ze starszymi iłami i piaskami oraz fragmentami węgla brunatnego zalegały wśród glin morenowych zlodowacenia środkowopolskiego (Piotrowski 1982). Po ociepleniu 
się klimatu i wytopieniu się lądolodu środkowopolskiego w okresie interglacjału eemskiego rozwinęła się sieć rzeczna nawiązująca do szkieletu sieci rzecznej z poprzednich okresów międzylodowcowych oraz do starszych głównych struktur tektonicznych (Schoeneich 1962). Procesy erozyjne odtwarzały niektóre starsze doliny rzeczne, które istniały już w paleogenie czy neogenie oraz w interglacjale wielkim (Dyjor 1991), rozcinając je i wypełniając osadami rzecznymi. Prawdopodobnie wówczas Wzgórza Szczecińskie zostały podzielone na leżący na południowym zachodzie Wał Stobniański oraz wzgórza Warszewskie (Karczewski 1968) rozdzielone doliną erozyjną odprowadzającą część wód w kierunku południowo-wschodnim (Niecka Niebuszewa). Wraz z rozwojem roślinności pojawiały się w osadach rzecznych i zastoiskowych muły organiczne i torfy. Zlodowacenie północnopolskie znacznie przemodelowało podłoże. W czasie nasunięcia fazy maksymalnej (leszczyńskiej) złożona została pokrywa glin morenowych o nie zawsze ciągłym charakterze. Część osadów zlodowacenia środkowopolskiego została wyerodowana na wschód i zachód od Wzgórz Warszewskich (Piotrowski 1982), a szczytowe partie zostały częściowo zaburzone i ścięte egzaracyjnie.

Podczas deglacjacji lądolodu występowała zarówno akumulacja, jak i erozja materiału wodnolodowcowego. Przy arealnym zaniku lądolodu z fazy pomorskiej na obszarze wzgórz Warszewskich tworzy się szereg form szczelinowego pochodzenia. Topniejący lądolód zostawił serie piasków lodowcowych, piasków i mułków teras kemowych, a w warunkach subglacjalnych nawet fragmenty form ozowych. W dalszym etapie deglacjacji tworzą się poziomy terasowe równiny Odrzańsko-Zalewowej (Karczewski 1968, 2007). Najwyższy z nich (IV) sięga rzędnej ponad $20 \mathrm{~m}$ n.p.m. i dochodzi do terasy kemowej północnej i północnozachodniej części wzgórz Warszewskich.

$\mathrm{Na}$ Wzgórzach Warszewskich rozwijały się procesy erozyjno-denudacyjne. Powstawały wtedy dolinki erozyjne o promienistym przebiegu. Po zmianie reżimu hydraulicznego z południowego na północny nastąpiło szybkie obniżenie bazy erozyjnej i wzmożenie intensywności procesów erozyjnych. Powstały najniższe terasy Równiny Odrzańsko-Zalewowej. Pogłębione zostały wówczas liczne dolinki erozyjne ze stożkami napływowymi u ich wylotach. W warunkach peryglacjalnych zachodzą $\mathrm{w}$ dalszym ciągu intensywne procesy denudacyjne na stokach wysoczyzny. Przebieg dolinek uzależniony jest od litologii podłoża (Piotrowski 1982). Część tych dolinek jest obecnie zawieszona i nawiązuje do poziomu teras rzecznorozlewiskowych.

$\mathrm{Z}$ okresu przełomu plejstocenu i holocenu pochodzą pokrywy eoliczne maskujące lokalnie rzeźbę. Występują one zarówno na obszarze teras kemowych „przyklejonych” do Wzgórz Warszewskich, jak i na wierzchowinach morenowych jako niewielkie wydmy oraz równiny piasków przewianych (Piotrowski 1982). Typowe paraboliczne wydmy występują na północny-wschód na obszarze 
Równiny Wkrzańskiej, wskazując na zachodnią cyrkulację na przełomie plejstocenu i holocenu (Stankowski 1963). Baza erozyjna, jakim była Odra w okresie jeziora Ancylusowego znajdowała się na rzędnej ok. $-15 \mathrm{~m}$ n.p.m., stąd wąskie i głębokie dolinki odprowadzające wody z obszaru wysoczyzny. W tym czasie rozwijały się ruchy masowe w strefie krawędziowej wysoczyzny. Różnica wysokości między wierzchowinami a ówczesną doliną Odry wynosiła kilkadziesiąt metrów na niewielkich odcinkach. W okresie Atlantyckim w czasie transgresji litorynowej znacznie podniósł się poziom Bałtyku i nastąpiło powolne zasypywanie dna rzeki osadami aluwialnymi. Ujściowe stożki dolinek cieków ulegały powolnemu zatorfieniu. $\mathrm{W}$ dnach niektórych dolinek również pojawiły się osady organiczne (torfy i namuły) przykryte później piaskami, a nawet glinami deluwialnymi. W okresie historycznym obszar Wzgórz Warszewskich został znacznie przekształcony antropogenicznie. Wraz z rozbudową miasta część terenów przeznaczano pod zabudowę. We wschodniej części dolnej strefy krawędziowej u podnóża wysoczyzny od końca XIX w. rozwinęła się dzielnica przemysłowa miasta (huta, papiernia, stocznie, fabryka chemiczna), liczne cegielnie funkcjonujące na bazie miejscowego surowca, jakim są oligoceńskie iły septariowe występujące na całym obszarze jako porwaki przedczwartorzędowe wśród osadów lodowcowych. Wybudowane nabrzeża portowe wzdłuż Odry, a pod koniec XIX w. linia kolejowa przyczyniły się do rozwoju urbanizacyjnego obszaru.

\section{CHARAKTERYSTYKA HYDROGEOLOGICZNA}

Pod względem hydrogeologicznym omawiany obszar należy do plejstoceńskiej wysoczyzny morenowej. Postglacjalne dolinki (Matkowska 1983) wykorzystywane są przez źródła i cieki, które zbierają wodę, tworząc system drenażowy wód podziemnych. Cały obszar zalicza się do obszarów o skomplikowanych warunkach hydrogeologicznych. Poziom wody gruntowej występuje na różnych głębokościach. Woda infiltracyjna charakteryzuje się swobodnym zwierciadłem. W licznych soczewkach i przewarstwieniach piaszczystych zwierciadło wody gruntowej występuje pod ciśnieniem. Poziom stabilizacji wód podziemnych jest na bardzo różnych głębokościach. Związane jest to z orografią wysoczyzny oraz przestrzennym ułożeniem warstw przepuszczalnych (piaski i żwiry), słabo przepuszczalnych (piaski gliniaste, pyły piaszczyste, pyły i gliny) oraz nieprzepuszczalnych (iły pylaste i iły). Jeden główny poziom stabilizuje się na poziomie morza (Odry). Nie ma on jednak istotnego wpływu na własności geologicznoinżynierskie podłoża budowlanego w strefie krawędziowej wysoczyzny Poziom wodonośny tworzą dwie lub trzy przepuszczalne warstwy osadów wodnolodowcowych i zastoiskowych. W zachodniej części Wysoczyzny znajduje się ujęcie wód podziemnych (Pilchowo), a w północnej ujęcie Mścięcino oraz znajdujące 
się na Wysoczyźnie ujęcie Skolwin. Południowe i wschodnie stoki wysoczyzny są znacznie przekształcone antropogenicznie (obszar intensywnie zabudowany) i przy intensywnych opadach deszczu zdarzają się lokalne podtopienia, a niekiedy wzrost erozji bocznej w ciekach, zaś istniejący system burzowo-kanalizacyjny nie zawsze jest w stanie odprowadzić nadmiar wód opadowych. Na stokach niepokrytych roślinnością występują intensywne procesy ablacji deszczowej, a u podnóża stoku zdarzają się wysięki i młaki.

\section{CHARAKTERYSTYKA GEOLOGICZNO-INŻYNIERSKA STREFY KRAWĘDZIOWEJ}

Pod względem geologiczno-inżynierskim całą strefę krawędziową wysoczyzny Wzgórz Warszewskich można podzielić na trzy podstawowe części.

1. część wysoczyznowa z górną krawędzią stoku (miejsce infiltracji wód opadowych),

2. stok (zbocze), niekiedy rozcięte dolinką erozyjną (obszar spływu wód powierzchniowych i gruntowych),

3. podnóże stoku (miejsce gromadzenia się osadów stokowych oraz wysięku wód gruntowych).

W części wysoczyznowej w podłożu gruntowym wśród gruntów niespoistych występują przeważnie piaski drobne i średnie wilgotne. Są one średniozagęszczone. Grunty spoiste reprezentowane są przez morenowe piaski gliniaste, gliny piaszczyste i gliny oraz przemieszane z nimi brązowe, oliwkowe, szare i nawet czarne oligoceńskie iły pylaste. Grunty spoiste są przeważnie wilgotne w stanie twardoplastycznym, a nawet półzwartym. Posadowienie obiektów inżynierskich z reguły nie nastręcza problemów. Jednak w miejscach, gdzie występują płytko zaburzone i złuskowacone iły oligoceńskie zaczynają się pojawiać problemy z posadowieniem obiektów oraz ich zabezpieczeniem przed niekorzystnymi procesami geodynamicznymi, doprowadzające niekiedy do awarii budowlanej w przypadku nadmiernego nawilgocenia iłów oligoceńskich, wśród których dominują minerały z grupy smektytu i illitu. Grunty te pod wpływem wilgoci podlegają pęcznieniu i znacznie zwiększają swoją objętość. Przykładem może być awaria budynku dwukondygnacyjnego przy ul J. Dierżonia w dzielnicy Szczecin-Warszewo. Podczas wykonywanych w latach osiemdziesiątych XX w. prac ziemnych związanych $\mathrm{z}$ budową ciepłociągu dla tej dzielnicy zostały przerwane stare funkcjonujące od początku XX w. systemy melioracyjne, które utrzymywały stałą wilgotność w iłach. Po zniszczeniu systemu drenarskiego wody opadowe, nie mogąc odpływać, znacznie nawilgotniły iły, które zwiększając swoją objętość, przyczyniły się do znacznego popękania budynku. Podobna sytuacja miała miejsce w innym miejscu Szczecina, gdzie podłożem budowlanym są zaburzone iły oligoceńskie, wśród których znajdują się niewielkie soczewki i wkładki piaszczyste. Przy budowie 
sieci kanalizacyjnej i wodociągowej wzdłuż ulicy wykonano wykop, który nie został zabezpieczony. Po opadach deszczu pojawiła się woda w wykopie, uplastyczniając grunty ilaste. Uruchomiły się wówczas procesy osuwiskowe, przyczyniając się do powstania znacznych pęknięć ścian budynku (Paczkowska, Seul 2009).

Na obszarze wysoczyznowym w miejscu źródliskowym cieku Warszewiec znajdują się przykryte piaskami deluwialnymi grunty organiczne o miąższości nawet kilku metrów. Wymusza to konieczność pośredniego posadowienia, co znacznie podnosi koszty budowy. Posadowienie obiektów na zboczach strefy krawędziowej jest bardziej utrudnione.

Występują w tej strefie znaczne nachylenia terenu, a przy często zmiennym i zaburzonym ułożeniu warstw geologicznych prawidłowe rozpoznanie nastręcza wiele problemów. Do utworów morenowych niekiedy „doklejone” są np. utwory terasy kemowej, które maskują glacjalne podłoże. Przy zmianach warunków wilgotnościowych uruchamiają się często procesy osuwiskowe, co w efekcie doprowadza do awarii budowlanych. Obszar strefy krawędziowej charakteryzuje się złożonymi i skomplikowanymi warunkami geologiczno-inżynierskimi. Przy omawianiu tej strefy zostaną podane przykłady awarii budowlanych występujących na tym obszarze z uwzględnieniem przyczyn i skutków.

Przykładem może być awaria budynków mieszkalnych posadowionych na południowym stoku wysoczyzny przy ul. Lompy w Szczecinie (Bryl 1989, 1992). Zbocze to charakteryzuje się niewielkim nachyleniem $(<5 \%)$. Jednak zaburzone iły oligoceńskie przykryte kemowymi osadami pylastymi i piaskami drobnymi przy zwiększeniu wilgotności stanowiły powierzchnię poślizgu osadów nadległych, na których posadowione były ławy fundamentowe. Dodatkową przyczyną pękania budynków było nierównomierne osiadanie z tytułu niezakończonego procesu konsolidacji iłów oraz zmian wilgotnościowych wynikających chociażby z nieszczelnej kanalizacji deszczowej.

Wybudowana linia kolejowa ze Szczecina do Trzebieży Szczecińskiej przechodzi przez tereny strefy krawędziowej wysoczyzny na obszarze iłów zaburzonych glacitektoniczne w dzielnicy Szczecina Żelechowa. Są to obszary osuwiskowe oraz o potencjalnych możliwościach rozwoju osuwisk. Do połowy lat sześćdziesiątych XX w. (prawie 100 lat eksploatacji tej linii kolejowej) nie zanotowano osuwania się torowiska. Wraz z budową Zakładów Chemicznych w Policach, wykonano podcięcie stoku i dobudowano drugi tor kolejowy. Podczas prac ziemnych wykonany został system drenarski mający regulować wilgotność podłoża zbudowanego z zaburzonych iłów septariowych. Podczas prac ziemnych zniszczony został (przynajmniej częściowo) stary drenaż ceramiczny wykonany podczas budowy linii kolejowej jeszcze w XIX w. Przez ponad 10 lat eksploatacji linii kolejowej nie zauważano niekorzystnych zjawisk geodynamicznych. W drugiej połowie lat siedemdziesiątych zostały zwiększone obciążenia dynamiczne przez zwiększanie nacisku na oś wagonów. Na skutek 
nieprawidłowo funkcjonującego drenażu nastąpiło nawilgotnienie iłów zalegających w podłożu, a dodatkowo zwiększone obciążenia dynamiczne spowodowały zjawisko tiksotropii, które uruchomiło procesy osuwiskowe. Efektem tego była w 1980 r. katastrofa polegająca na zsunięciu się torowiska (Błędzka, Bryl 1990). Po wykonaniu zabiegów zabezpieczających (zmiana geometrii skarpy), dodatkowy system odwodnień zatrzymał proces osuwania się torowiska. Po 7 latach (w 1988 r.) nastąpiło ponowne uruchomienie procesów osuwiskowych. Pomiary geodezyjne wykazały przemieszczenie poziome torów kolejowych o 1,6 m, a pionowe o $0,6 \mathrm{~m}$ (Błędzka, Bryl 1990). Wykonywane przez ponad rok badania inklinometryczne potwierdzały istniejące czynne osuwisko. Na linii kolejowej wykonywano tylko doraźne uzupełnienia podtorza, co doprowadziło w 1990 r. do dalszych osunięć i zamknięcia jednego toru. Prowadzone badania stateczności zbocza, a częściowo też skarpy, na której znajduje się torowisko dla plastycznych i twardoplastycznych iłów, często przewarstwionych piaskami, które dodatkowo nawilgatniają iły wyraźnie wskazują na utratę stateczności przy uwzględnieniu obciążeń dynamicznych (Bryl 1986; Błędzka, Bryl 1990)

Jednym z najbardziej klasycznych przykładów awarii budowlanych na skutek nie do końca przemyślanych działań inwestycyjnych jest wybudowanie w na początku lat siedemdziesiątych budynku socjalnego (stołówka) dla „Huty Szczecin" na czynnym osuwisku iłów oligoceńskich w dolnej strefie krawędziowej stoku przy ważnym szlaku komunikacyjnym (drogowym i kolejowym) ze Szczecina do Polic.

Po kilku latach eksploatacji widoczne były zarysowania budynku, a precyzyjne pomiary geodezyjne wykazały przemieszczenie się budynku o kilka centymetrów, a nawet niewielkie obrócenie względem kierunków świata. Po wybudowaniu Zakładów Chemicznych w Policach zarówno na drodze oraz linii kolejowej znacznie wzrósł ruch pojazdów. Nałożenie się kilku czynników przyczyniło się do wzmożenia procesów osuwiskowych:

- pierwszym z nich jest ukształtowanie terenu (znaczne nachylenie zbocza), co ułatwia rozwój ruchów masowych,

- następny to skomplikowana budowa podłoża (zaburzone osady),

- kolejnymi są podatne na zmiany wilgotnościowe i łatwo poddające się tiksotropii oligoceńskie iły septariowe,

- ostatni to wzmożony ruch pojazdów (obciążenia dynamiczne).

Wydawałoby się, że podnóże strefy krawędziowej jest pozbawione problemów z posadowieniem i eksploatacją obiektów inżynierskich. Jednakże i w tym obszarze napotyka się na niekorzystne zjawiska utrudniające prace ziemne i posadowienie obiektów oraz ich eksploatację. Obszar ten charakteryzuje się najmniejszymi spadkami terenu oraz prostymi i złożonymi warunkami gruntowymi. Budują go przeważnie grunty deluwialne i koluwialne. W obniżeniach zalegają 
grunty organiczne o miąższości nawet kilku metrów, które niekiedy są przykryte piaskami rzecznymi czy piaskami i glinami deluwialnymi. Wymaga to konieczności dokładnego zaprojektowania badań terenowych. Nie zawsze jest to zauważane przez projektantów. Podstawowym mankamentem tej strefy jest płytko zalegająca woda gruntowa. Ze względu na sąsiedztwo wysoczyzny o znacznych kumulacjach zwierciadło napięte ma charakter artezyjski. Podczas prac ziemnych przy przerwaniu warstwy gruntów nieprzepuszczalnych i słabo przepuszczalnych występuje zalewanie wykopów. Rozluźnione piaski zmniejszają swoje zagęszczenie, a nawet zdarzają się zjawiska sufozji polegającej na wypłukiwaniu drobniejszych cząstek i rozluźnieniu podłoża. Wraz z rozwojem miasta niektóre cieki czy obszary bagienne zostały zasypane. W centrach dawnych miast były zasypywane fosy i rozbierane mury. Na obrzeżach, przy braku dokumentacji archiwalnych, nie zawsze można określić przed przystąpieniem do prac terenowych, jakich gruntów można się spodziewać w podłożu. Mapa Geologiczna sprzed 1945 r. w skali 1:25 000 (Berendt 1921), podobnie jak Szczegółowa Mapa Geologiczna Polski w skali 1:50 000 dla rozwiązań geologiczno-inżynierskich jest za mało dokładna. Na przykład w obniżeniu Niecki Niebuszewskiej (podnóże Wzgórz Warszewskich) niektórzy projektanci projektują nadbudowę istniejących kilkadziesiąt lat budynków dwukondygnacyjnych, które nie wykazują np. żadnych spękań (prawidłowo posadowione i eksploatowane). Projektant - konstruktor liczy dodatkowe obciążenia, uwzględniając istniejące fundamenty i wykonując przy tym odkrywki fundamentów. Pod fundamentami przeważnie jest wykonana podsypka piaskowa i jeśli podłoże nie zostanie zbadane głębiej (co niestety się często zdarza), to jeśli na większych głębokościach będą występować grunty o słabszych parametrach wytrzymałościowych (np. pyły z gliny pylaste) podłoże może nie przenieść dodatkowego obciążenia i nastąpią typowe objawy nadmiernego czy nierównomiernego osiadania. W obniżeniu Niecki Niebuszewa znajduje się lokalnie nawet kilkumetrowa warstwa gruntów organicznych, często nadbudowana jedno- lub dwumetrową warstwą piasków rzecznych i deluwialnych, które przeniosą niewielkie obciążenia. Jednak przy dodatkowym dociążeniu obiektu może nastąpić np. utrata nośności lub większe od przewidywanego osiadanie.

\section{PODSUMOWANIE}

Rejon strefy krawędziowej wysoczyzny Wzgórz Warszewskich jako obszar młodoglacjalny nałożony na starsze struktury glacjalne należy do trudnych (skomplikowanych) zarówno pod względem ukształtowania powierzchni, jak i zróżnicowania osadów, co w konsekwencji prowadzi do różnorodności intensywności procesów geodynamicznych. 
Istniejące osady spoiste, które przeważają na omawianym obszarze (przemieszane, zaburzone i złuskowacone iły oligoceńskie z materiałem morenowym oraz gliny i pyły) wykazują znaczną podatność na zmiany wilgotnościowe podłoża. Wykazujące stabilność zbocza, zbudowane z iłów pod wpływem nawilgotnienia zmniejszają swoje parametry wytrzymałościowe. Np. septariowe iły oligoceńskie będące w stanie półzwartym $\left(\mathrm{I}_{\mathrm{L}}=0,0\right)$ charakteryzują się kątem tarcia wewnętrznego $(\boldsymbol{\varphi})$ nawet do $15^{0}$, spójnością (c) do $60-70 \mathrm{kPa}$ i modułem odkształcenia pierwotnego $\left(\boldsymbol{E}_{0}\right)$ około $30 \mathrm{MPa}$, lecz na skutek tiksotropii czy zwiększenia wilgotności naturalnej przechodzą do stanu plastycznego i miękkoplastycznego, obniżając znacznie swoje parametry. Kąt tarcia wewnętrznego $(\varphi)$ dla iłów oligoceńskich spada nawet do $0^{0}$, spójność (c) do $20 \mathrm{kPa}$, a moduł odkształcenia pierwotnego $\left(\boldsymbol{E}_{0}\right)$ nawet do poniżej $5 \mathrm{MPa}$. Uruchamiane są wówczas procesy osuwiskowe (utrata stateczności zbocza (stoku) czy bardzo powolne prawie niezauważalne w krótkim czasie ruchy pełzania gruntu.

Skomplikowane ułożenie warstw gruntu powoduje znaczne zróżnicowanie poziomu wody gruntowej nawet na obszarze przeznaczonym do posadowienia niewielkiego budynku jednorodzinnego, co może utrudnić prawidłowe zaprojektowanie posadowienia. Drenaż wód podziemnych w strefie krawędziowej, a szczególnie w jej dolnej części, powodując wysięki i młaki, nie sprzyja robotom ziemnym oraz czasem niekorzystnie wpływa na eksploatację obiektów budowlanych. W zaburzonych glacitekonicznie iłach pojawiają się niekiedy laminy piaszczyste, przez które przeciska się woda i nawet niewielkie sączenia wody (nie zawsze precyzyjnie oceniane podczas badań terenowych) mogą przyczynić się do zalewania wykopów czy już po wykonaniu inwestycji do nadmiernego zawilgocenia fundamentów i ścian.

Zbyt duża ingerencja w zmiany rzeźby terenu (budowa ulic i ciągów komunikacyjnych na obszarze o dużych spadkach), zmniejszenie retencji i zwiększenie spływu powierzchniowego przyczynia się do wzmożenia niektórych procesów geodynamicznych (np. ablacja deszczowa). Szczególnie jest to widoczne po deszczach nawalnych. Skutkiem tego są bruzdy erozyjne tworzące się podczas wymywania materiału i formowane stożki napływowe u podnóża form.

Jednym z trudniejszych do opanowania zjawisk jest pełzanie (proces powolny) oraz procesy osuwiskowe (głębokie niekiedy powierzchnie poślizgu) w iłach oligoceńskich czy zaburzonych glinach morenowych. 


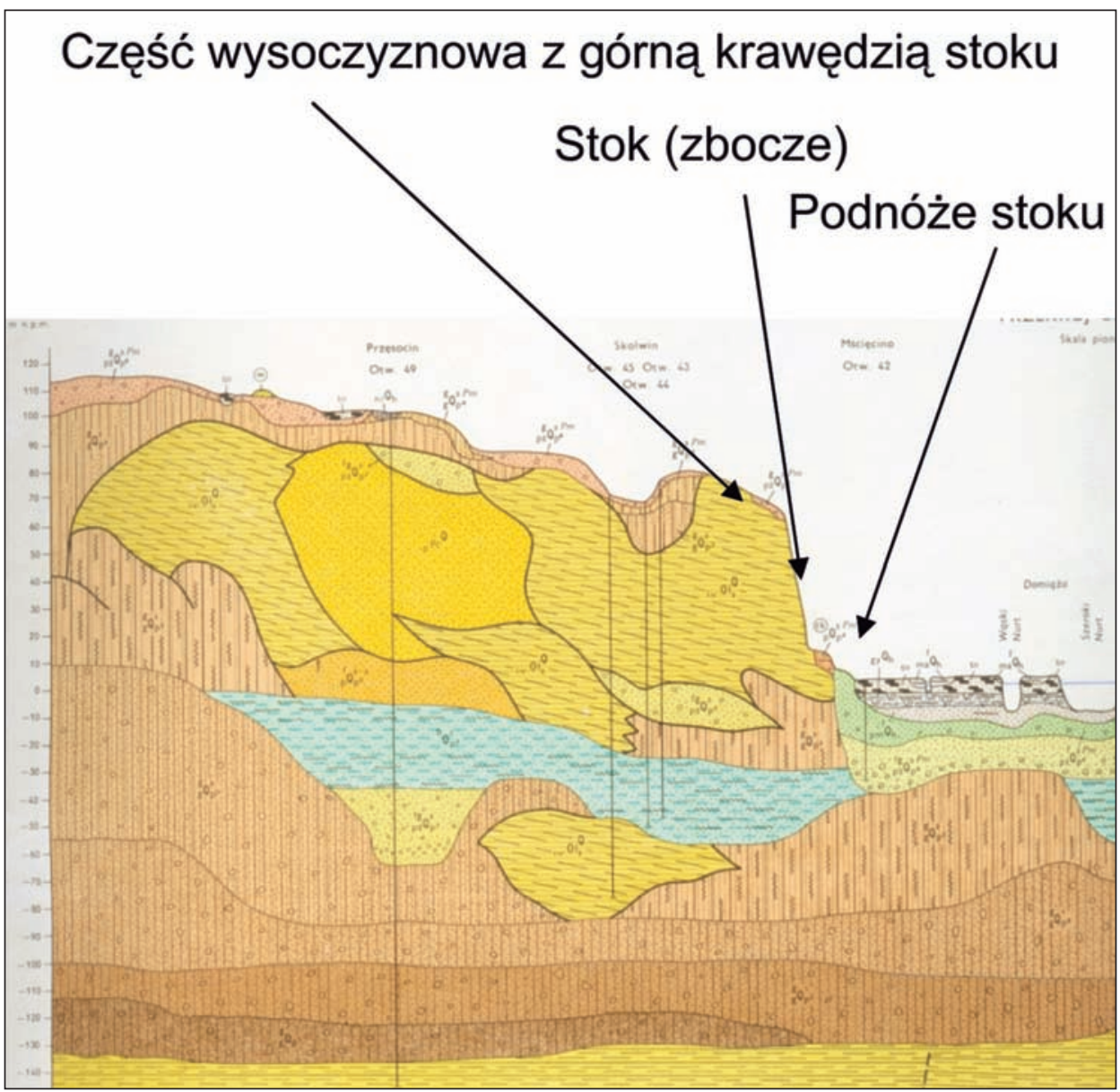

Ryc. 3. Strefa krawędziowa na tle przekroju geologicznego (Piotrowski 1982)

Fig. 3. The edge zone against the background of the geological cross section (Piotrowski 1982)

\section{LITERATURA}

Berendt F., 1921: Geologische Karte von Preussen und benachbarten Bundesstaten, Blatt Stettin, Berlin

Błędzka J., Bryl B., 1990: Analiza przyczyn osunięcia się skarpy nasypu kolejowego na linii Szczecin - Trzebież Szczecińska. Prace Naukowe Politechniki Szczecińskiej 418, IIW 35. Geotechnika VI, s. 135-144.

Borówka R. K., 2002: Środowisko Geograficzne, [w:] Przyroda Pomorza Zachodniego (red. R. K. Borówka) OFICYNA IN PLUS. Szczecin, s. 6-102.

Bryl B., 1986: Wielkość stref odkształceń plastycznych $w$ podłożu z iłów oligoceńskich $w$ rejonie osuwiskowym Stołczyna. Prace Naukowe Politechniki Szczecińskiej. IIW nr 322. Geotechnika II, s. 27-36. 
Bryl B., 1989: Przyczyny awarii obiektów budowlanych posadowionych na iłach trzeciorzędowych (szczecińskich). Prace Naukowe Politechniki Szczecińskiej 408, IIW 33, s. 135-144.

Bryl B., 1992: Zmiany wytrzymałościowe iłów zaburzonych glacitektoniczne przyczyna awarii budynków położonych przy ul. J. Lompy w Szczecinie. Prace Naukowe Politechniki Szczecińskiej 474. Katedra Geotechniki 3, s. 43-56.

Dadlez R., 1983: Tektonika podłoża podkenezoicznego między Szczecinem a Kotobrzegiem.

Dobracki R., 1982: Szczegółowa Mapa Geologiczna Polski 1:50000 ark Szczecin. Wydawnictwa Geologiczne. Warszawa.

Dobracki R., 1982: Objaśnienia do Szczegółowej Mapy Geologicznej Polski ark. Szczecin. Wydawnictwa Geologiczne. Warszawa.

Dyjor S., 1991: Wplyw ewolucji paleogeograficzne na rozwój zlodowaceń w Polsce Zachodniej, [w:] A. Kostrzewski (red.) Geneza, litologia i stratygrafia utworów czwartorzędowych. Geografia 50, s. 419-433. Wydawnictwa Naukowe. UAM Poznań.

Karczewski A., 1968: Wplyw recesji lobu Odry na powstanie i rozwój sieci dolinnej Pojezierza Myśliborskiego i Niziny Szczecińskiej. PTPN. Wydz. Mat.-Przyr. Prace Komisji Geograficznogeologicznej, t. 8, z. 3. Poznań.

Karczewski A., 2007: Geomorfologia Pojezierza Myśliborskiego i Niziny Szczecińskiej skala 1: 200 000. Instytut Paleogeografii i Ekologii. Uniwersytet im. A. Mickiewicza w Poznaniu.

Kondracki J., 2000: Geografia fizyczna Polski. PWN Warszawa.

Kowalski W. C., 1988: Geologia inżynierska. Wydawnictwa Geologiczne. Warszawa.

Lindner L., Marks L., 1995: Zarys Paleomorfologii obszaru Polski podczas zlodowaceń skandynawskich. Przegląd Geologiczny, t. 43, nr 7, s. 586-596.

Malinowski J., Watycha L., 1958: Przegladowa Mapa Geologiczno-inżynierska Polski 1:300000 ark. B1 Szczecin. Indstytut Geologiczny. Warszawa.

Maliszewski N., Piotrowski A., 1983: Charakterystyka procesów masowych w krawędziowej partii Wzgórz Warszewskich - dolina Żółwinki. Przewodnik LV Zjazdu PTG (W. Grocholski red.). Szczecin 15-17 września 1983, s. 7-20. Wydawnictwa Geologiczne Warszawa.

Makowska Z., 1983: Warunki hydrogeologiczne wysoczyzny Wzgórz Warszewskich na przykładzie ujęcia ,,Skolwin”. Przewodnik LV Zjazdu PTG (W. Grocholski red.). Szczecin 15-17 września 1983, s. 168-169. Wydawnictwa Geologiczne Warszawa.

Marek S. (ed.), 1997: Epikontynentalny perm i mezozoik w Polsce. Prace Państwowego Instytutu Geologicznego CLIII. Warszawa.

Mojski J.E., 1977: Mapa Geologiczna Polski 1:200000 ark. Szczecin. Wydawnictwa Geologiczne Warszawa.

Mojski J.E., 2005: Ziemie polskie w czwartorzędzie. Zarys morfogenetyczny. Państwowy Instytut Geologiczny. Warszawa, ss. 404.

Paczkowska T., Seul C., O przyczynach zarysowań i osuwania się pewnego budynku w Szczecinie. Przegląd Budowlany nr 11, s. 32-36.

Piotrowski A., 1982: Szczegółowa Mapa Geologiczna Polski 1:50 000 ark Police. Wydawnictwa Geologiczne. Warszawa.

Piotrowski A., 1982: Objaśnienia do Szczegółowej Mapy Geologicznej Polski ark. Police. Wydawnictwa Geologiczne. Warszawa.

Piotrowski A. Budowa geologiczna i warunki powstania Wzgórz Warszewskich. Przewodnik LV Zjazdu PTG (W. Grocholski red.). Szczecin 15-17 września 1983, s. 7-20. Wydawnictwa Geologiczne Warszawa.

Schoeneich K., 1962: Żywe procesy tektoniczne w pótnocno-zachodniej Polsce. Szczecińskie Towarzystwo Naukowe. Wydział Nauk Technicznych, t III, z. 1. Szczecin.

Stankowski W., 1963: Rzeźba eoliczna Polski pótnocno-zachodniej na podstawie wybranych obszarów. PTPN. Wydz. Mat. - Przyr. Prace Kom. Geogr.-geolog., t. 4, z. 1. Poznań. 
Stupnicka E., 1989: Geologia regionalna Polski. Wydawnictwa Geologiczne. Warszawa. http://gis.um.szczecin.pl/UMSzczecinGIS/chapter_85000.asp.

\section{SUMMARY}

Development trends of the modern city imply a reduction in the number of inhabitants in its centre, and thus the construction of dormitory suburbs on the outskirts of the city. One of the potential areas for the development of Szczecin is its northern part, i.e. the so-called Warszewo Hills. This area has both latitudinal and meridional extents of about $8 \mathrm{~km}$, and is characterized by complicated engineering-geological conditions. It lies at altitudes ranging from the sea level (Odra River) to $130.9 \mathrm{~m}$ a.s.l. (Wielecka Góra), and has highly varied relief. Its landscape consists of hills and flat plateaux, which are cut by deep small valleys, some of them with streams (e.g. the Warszewiec stream). Geological structure is characterized by the occurrence of glacitectonically disturbed moraine deposits mixed with the Tertiary sands and clays. Taking into account geodynamic processes and their intensity, the wide edge zone of the Warszewo Hills can be divided into three main parts: plateau with the upper edge of slope (area of precipitation infiltration), slope, which is cut by small erosion valleys in places (area of surface water and groundwater flow), slope foot (area of water flow and accumulation of slope deposits). One of the most important tasks of the design-investment process is to take action in such a way as to interfere as little as possible in the natural environment and at the same time to achieve the intended purpose. Predominant occurrence of cohesive deposits in the described area (Oligocene scaled clay mixed with moraine disturbed material) results in a high susceptibility of ground to moisture changes. Strength parameters of stable slopes built of clays considerably decrease under the influence of increasing moisture and thixotropy phenomenon. Then landslide processes are triggered, as well as very slow, hardly noticeable in a short time, soil creep. The complicated arrangement of deposit layers results in spatial variability of groundwater level, and proper design of building foundation is difficult, even in the case of a small, detached house. Too much interference in the landform features (through macro-levelling, construction of streets and routes in the area with steep slopes), the decrease of water retention and increase of surface runoff contribute to an intensification of some geodynamic processes. 